Highlights.

- Wastes from $\mathrm{Cr} / \mathrm{Ni} / \mathrm{Cu}$ plating have been checked as black pigment in glazes.

- Dried wastes (110 C) are gray but color changes to black upon firing (1000 C).

- Dried wastes produce glaze defects (pin-holing and crawling).

- Fired powders (1000 C) do not induce glaze defects, giving intense black colors. 


\title{
RECYCLING OF Cr/Ni/Cu PLATING WASTES AS BLACK CERAMIC PIGMENTS
}

\author{
C. Gargori ${ }^{\mathrm{a}}$, S. R. Prim ${ }^{\mathrm{b}}$, M. LLusar ${ }^{\mathrm{a}}$, M.V. Folgueras ${ }^{\mathrm{b}}$, G. Monrós ${ }^{\mathrm{a}}$.
}

${ }^{a}$ Dpt. of Inorganic and Organic Chemistry, Jaume I University, Av. de Vicent Sos Baynat, s/n. 12071, Castellón (Spain)

${ }^{b}$ Centro de Ciências Tecnológicas, Universidade do Estado de Santa Catarina (UDES), Joinville (Brasil).

\begin{abstract}
.
The non-ferrous metal industry, such as $\mathrm{Cr} / \mathrm{Ni} / \mathrm{Cu}$ plating, produces acid sludge which is usually neutralized with lime slurry in batch processes, and the resulting waste is dewatered by vacuum filtration or filter-pressing. Dewatered sludge contains calcium sulphate $\left(\mathrm{CaSO}_{4}\right)$ coming from the neutralization process, as well as transition metals $(\mathrm{Cr}, \mathrm{Ni}$ and $\mathrm{Cu})$, oil, grease and suspended solids. In this communication, two residual sludges from $\mathrm{Cr} / \mathrm{Ni} / \mathrm{Cu}$ plating have been dried $\left(110{ }^{\circ} \mathrm{C}\right)$ and fired $\left(1100{ }^{\circ} \mathrm{C}\right)$, and both dried (gray coloured) and fired powders (black coloured) have been characterized by DTA-TG, XRD and SEM-EDX techniques. XRD shows only quartz crystallization in dried samples, while $\mathrm{NiCr}_{2} \mathrm{O}_{4}$ chromite spinel and $\mathrm{NiO}$ periclase crystallize in fired powders, along with $\mathrm{CaSO}_{4}$ anhydrite and $\mathrm{CaSiO}_{3}$ wollastonite. The powders have been introduced as ceramic pigments into three different conventional glazes: a) a lead bisilicate $\left(\mathrm{PbO} .2 \mathrm{SiO}_{2}\right)$ double fire frit $\left(1000^{\circ} \mathrm{C}\right)$, b) a double fire frit with low lead content $\left(1000^{\circ} \mathrm{C}\right)$, and c) a double fire frit without lead $\left(1050^{\circ} \mathrm{C}\right)$. Glazed samples were characterized by UV-Vis-NIR (diffuse reflectance) and CIEL*a*b* (color parameters). Dried powders induce glaze defects (pin-holing and crawling), but fired powders did not show these faults exhibiting more intense (higher $\mathrm{L}^{*}$ ) and yellowish (higher $\mathrm{b}^{*}$ ) black colors than the standard spinel.
\end{abstract}

Keywords: plating wastes, ceramic pigment, recycling, circular economy

\section{Introduction.}

Hazardous wastes management has gained increasing interest in the last decades due to environmental concerns and the recognition that natural resources are limited. The valorization of wastes, and specially the hazardous wastes, is a "green" target and involves economic benefits to companies associated to the waste transformation into new resources and minimizing the disposal costs in landfill. The waste valorization is inscribed into the concept of circular economy that, going beyond the current extractive industrial model based on "take, make and dispose", is restorative and regenerative by design. Relying on system-wide innovation, it aims to redefine products and services to design waste out, while minimizing negative impacts. Underpinned by a transition to renewable energy sources, the circular model builds the economic, natural and social capital [1], resting on three principles: a) Preserve and enhance natural capital by controlling finite stocks and balancing renewable resource flows; $b$ ) Optimize resource yields by circulating at all times products, components, and materials in both technical and biological cycles; c) Foster system effectiveness by revealing and avoiding negative externalities. This includes reducing damage to systems and areas such as food, mobility, shelter, education, health and entertainment, and managing externalities, such as land use, air, water and noise pollution, and the release of toxic substances. Literature is prolific in examples of production of ceramic pigments from residues [2,3], but their industrial applications are scarce due to concerns related to its low pigmenting capacity, low confidence in its chemical stability and the treatment costs of the powders for its application as pigments 
(normally they require a previous elimination of toxics and always a preliminary calcination). Therefore, it is necessary to attain an acceptable coloring capacity (in comparison with commercial pigments) and a stable composition of the residues for conferring the products a stable color. It must be highlighted that the use of industrial wastes as secondary raw materials is a very interesting eco-purpose, but it is also necessary for the proposed procedure to accomplish the sustainability requirements in agreement with the circular economy concept. In this sense there are three important aspects to analyze [4]:

a) The comparative results with similar commercial products (in this case ceramic pigments) in order to analyze the feasibility of substitution.

a) Worker's health and safety. It is necessary to analyze the hazardous characteristics of the proposed wastes. If a material does not fulfill the safety concerns, its sustainability is low and must be either purified (or stabilized) or discarded.

b) Pollution transference. The presence on the wastes of organic pollutants and volatile pollutants (e.g. $\mathrm{SO}_{2}, \mathrm{CN}^{-}$, halogens...) will produce the transference of pollutants from wastes to air.

The non-ferrous metal industry, such as $\mathrm{Cr} / \mathrm{Ni} / \mathrm{Cu}$ plating, produces acid sludge which is usually neutralized with lime slurry in batch processes, and the resulting waste is dewatered by vacuum filtration or filter-pressing. Dewatered sludge contains calcium sulphate $\left(\mathrm{CaSO}_{4}\right)$, a product of the neutralization process, as well as $\mathrm{Cr}, \mathrm{Ni}, \mathrm{Cu}$ and oil, grease and suspended solids. There has been a great interest in the ceramic industry for developing high stable pigments that show intense tonalities and also that comply with technological and environmental demands. Industrial processes like aluminum anodizing and powder surface coating or $\mathrm{Cr} / \mathrm{Ni}$ plating consume large amounts of water. As a result, a huge flow of wastewater has to be treated yielding high amounts of sludge. Traditionally, waste products are disposed of as soil conditioners or in land filling. More recently, recycling methods of such waste products have emerged as interesting alternative procedures [5]. In this communication, two residual sludges from $\mathrm{Cr} / \mathrm{Ni} / \mathrm{Cu}$ plating were dried $\left(110^{\circ} \mathrm{C}\right)$ and fired $\left(1100{ }^{\circ} \mathrm{C}\right)$, and then both the dried (gray colored) and fired (black colored) powders were added to ceramic glazes to measure its pigmenting capacity compared with a commercial black pigment based on the Fe-Cr-Mn spinel.

\section{Material and methods.}

Two residual sludges coming from the $\mathrm{Cr} / \mathrm{Ni} / \mathrm{Cu}$ plating industry were dried $\left(110^{\circ} \mathrm{C}\right)$ and fired $\left(1100{ }^{\circ} \mathrm{C} / 1 \mathrm{~h}\right)$. Then, both dried (gray colored) and fired (black colored) powders were $5-\mathrm{wt} \%$ added to three kinds of glazes (see oxide composition of the ceramic frits in Table 1): (I) a lead bisilicate $\left(\mathrm{PbO} .2 \mathrm{SiO}_{2}\right)$ double fire frit $\left(1000{ }^{\circ} \mathrm{C}\right)$, (II) a double fire frit with low lead content $\left(1000{ }^{\circ} \mathrm{C}\right)$, and (III) a double fire frit without lead $\left(1050{ }^{\circ} \mathrm{C}\right)$.

Samples were characterized by the following techniques: a) X-Ray Diffraction (XRD) was carried out on a Siemens D5000 diffractometer using $\mathrm{Cu} \mathrm{K} \mathrm{K}_{\alpha}$ radiation, 10-70 ${ }^{\circ} 2 \theta$ range, scan rate $0.02^{\circ} 2 \theta / \mathrm{s}, 4 \mathrm{~s}$ per step and $40 \mathrm{kV}$ and $20 \mathrm{~mA}$ conditions, b) DTA-TG thermal analysis was performed (with a heating speed of $5{ }^{\circ} \mathrm{C} / \mathrm{min}$ ) in a TGA/SDTA851e/LF/1600 equipment supplied by Mettler Toledo, c) UV-Vis-NIR spectra of both powders and $5 \mathrm{wt} \%$-glazed samples were collected using a Jasco V670 spectrometer through diffuse reflectance technique, d) $\mathrm{L}^{*} \mathrm{a} \mathrm{b}^{*}$ color parameters of glazed samples were measured following the CIE-L*a*b* (Commission International de l'Eclairage) colorimetric method using a X-Rite SP60 spectrometer, with standard lighting D65 and $10^{\circ}$ observer. On this method, $\mathrm{L}^{*}$ is a measure of lightness $(100=$ white, $0=$ black $)$, while $\mathrm{a}^{*}$ and $\mathrm{b}^{*}$ measure the chroma $\left(-\mathrm{a}^{*}=\right.$ green, $+\mathrm{a}^{*}=$ red, $-\mathrm{b}^{*}=$ blue, $+\mathrm{b}^{*}=$ yellow), e) Microstructure characterization of powders was carried out by 
Scanning Electron Microscopy (SEM), using a Leo-440i microscope supplied by LEYCA.

\section{Results and discussion.}

Table 1 displays SEM micrographs and the oxide composition of frits obtained by EDX analysis and Table 2 shows SEM micrographs and the oxide composition of wastes (dried and fired), which was also obtained by EDX analysis. XRD patterns of dried and fired wastes are shown in Figure 1: in dried powders only quartz crystallization is detected, while in fired powders $\mathrm{NiCr}_{2} \mathrm{O}_{4}$ chromite spinel and $\mathrm{NiO}$ periclase crystallize along with $\mathrm{CaSO}_{4}$ anhydrite and $\mathrm{CaSiO}_{3}$ wollastonite. DTA-TG thermal analyses of dried samples are shown in Figure 2.a. As it may be appreciated, both dried wastes show a sharp exothermic DTA band at $345{ }^{\circ} \mathrm{C}$ associated to the combustion of the oil and grease contained in the wastes, and this process is accompanied by a weight loss at TG analysis around 15 and $14 \%$ for R1S and R2S, respectively. Moreover, both samples lose $5 \mathrm{wt} \%$ and $8 \mathrm{wt} \%$ at $445{ }^{\circ} \mathrm{C}$ and $1100{ }^{\circ} \mathrm{C}$, respectively, which would be associated to the reactions between residual lime and sulphate and quartz $\left(445^{\circ} \mathrm{C}\right)$ and thermal decomposition of anhydrite $\left(1100^{\circ} \mathrm{C}\right)$ respectively. In addition, a very weak exothermic DTA band is observed at $710^{\circ} \mathrm{C}$, that could be associated to the detected crystallizations, such as the chromite spinel [6]. The total weight loss amount evaluated from TG analysis or LOI (Lost of Ignition in Table 2) are similar. On the other hand, the DTA-TG analyses of fired wastes (R1C and R2C) show that these wastes still lose weight at $1100{ }^{\circ} \mathrm{C}(12$ and $6 \%$ for $\mathrm{R} 1 \mathrm{C}$ and $\mathrm{R} 2 \mathrm{C}$, respectively), that would be associated to the decomposition of residual anhydrite.

Regarding to their coloring properties once introduced as ceramic pigments into three different conventional glazes, the dried powders produce glaze defects (pin-holing and crawling), but fired powders did not show these faults, giving rise to colored glazes exhibiting colorations ranging from gray to pure black. In Table 3 the black colors are compared with those obtained with a commercial Fe-Cr-Mn black spinel as standard reference: it can be pointed out that fired wastes produce more intense black colors, showing lower $\mathrm{L}^{*}$ values than the standard spinel, but shift to a yellow shade showing $a^{*}$ values around 3-5. In agreement with $L^{*} a^{*} b^{*}$ parameters (Table 3), the UV-Vis-NIR spectra shown in Figure 2.b indicate that dried powders increase the overall absorbance when glazed (indeed, $\mathrm{L}^{*}$ values also decrease). The fired powders R1C and R2C show more stable or constant absorbance levels (and also on its $\mathrm{L}^{*}$ values) that are similar to absorbance of the powder in frit II, slightly higher in Frit III and slightly lower in Frit I.

\section{Conclusions.}

Two residual sludges from $\mathrm{Cr} / \mathrm{Ni} / \mathrm{Cu}$ plating have been dried $\left(110^{\circ} \mathrm{C}\right)$ and fired $\left(1100^{\circ} \mathrm{C}\right)$ and then both the dried (gray colored) and fired (black colored) powders have been added to glazes in order to check its pigmenting capacity compared with a commercial black pigment based on $\mathrm{Fe}-\mathrm{Cr}-\mathrm{Mn}$ spinel. The obtained results indicate that the fired powders still show a weight loss at $1100{ }^{\circ} \mathrm{C}$ that would be associated to release of $\mathrm{SO}_{2}$ from anhydrite decomposition, and this instability could compromise its safe handling as a pigment. On the other hand, dried powders produce defects in the glaze (pin-holing and crawling), but fired powders did not show these faults, giving more intense black colors than the standard spinel, although the tone slightly shifts to yellow.

\section{Acknowledgements.}

The authors gratefully acknowledge the financial support of Universitat Jaume I (P1.1B2015-19 Project) and Spanish MINECO and FEDER founds (MAT2015-69443-Project). 


\section{References}

[1] Ellen MacArthur Foundation, Growth Within: a circular economy vision for a competitive Europe, SUN, McKinsey \& Co., June 2015.

[2] G. Costa, V.P. Della, M.J. Ribeiro, A.P.N. Oliveira, G. Monrós, J.A. Labrincha, Synthesis of black ceramic pigments from secondary raw materials, Dyes and Pigments 77(2008)137-144, doi: 10.1016/j.dyepig.2007.04.006.

[3] R. Galindo, I. Padilla, R. Sánchez-Hernández, J.I. Robla, G. Monrós, A. López-Delgado. Production of added-value materials from a hazardous waste in the aluminium tertiary industry: Synergistic effect between hydrotalcites and glasses, Journal of Environmental Chemical Engineering 3(2015)2552-2559, doi: 10.1016/j.jece.2015.09.012

[4] S. H. Jenkins, Analytical test in relation to the discharge of trade effluents to sewers pp. 248-264, in Waste treatment, P.C.G. Issac ed., Pergamon Press, London, 1960.

[5] G. Costa, M. J. Ribeiro, T. Trindade, J. A. Labrincha, Development of waste-based ceramic pigments, Bol. Soc. Esp. Ceram. V., 46 [1] (2007) 7-13

[6] S. K. Durrani, S. Z. Hussain, K. Saeed, Y. Khan, M. Arif, N. Ahmed, Hydrothermal synthesis and characterization of nanosized transition metal chromite spinels, Turk J. Chem. 36 (2012)111-120, doi:10.3906/kim-1104-6. 
Figure 1. XRD of wastes 1 and 2. CRYSTALLINE PHASES: Q(Quartz), A(Anhydrite $\left.\mathrm{CaSO}_{4}\right)$, $\mathrm{S}\left(\right.$ Spinel $\left.\mathrm{NiCr}_{2} \mathrm{O}_{4}\right), \mathrm{N}($ Periclase $\mathrm{NiO}), \mathrm{W}\left(\right.$ Wollastonite $\left.\mathrm{CaSiO}_{3}\right)$.
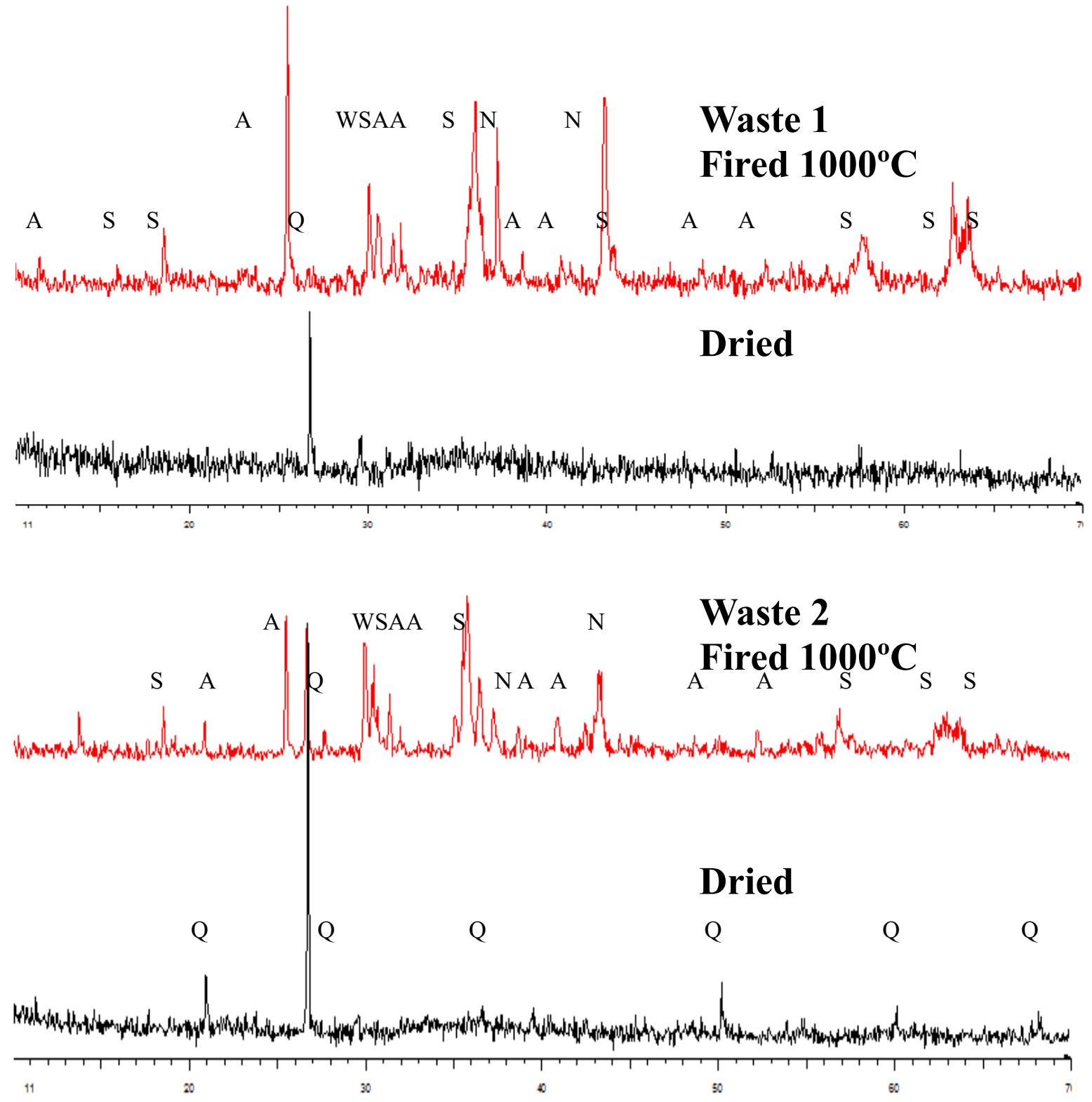
Figure 2. a) DTA-TG of wastes (dried and fired), b) UV-Vis-NIR of powders and 5wt $\%$ glazed tablets.
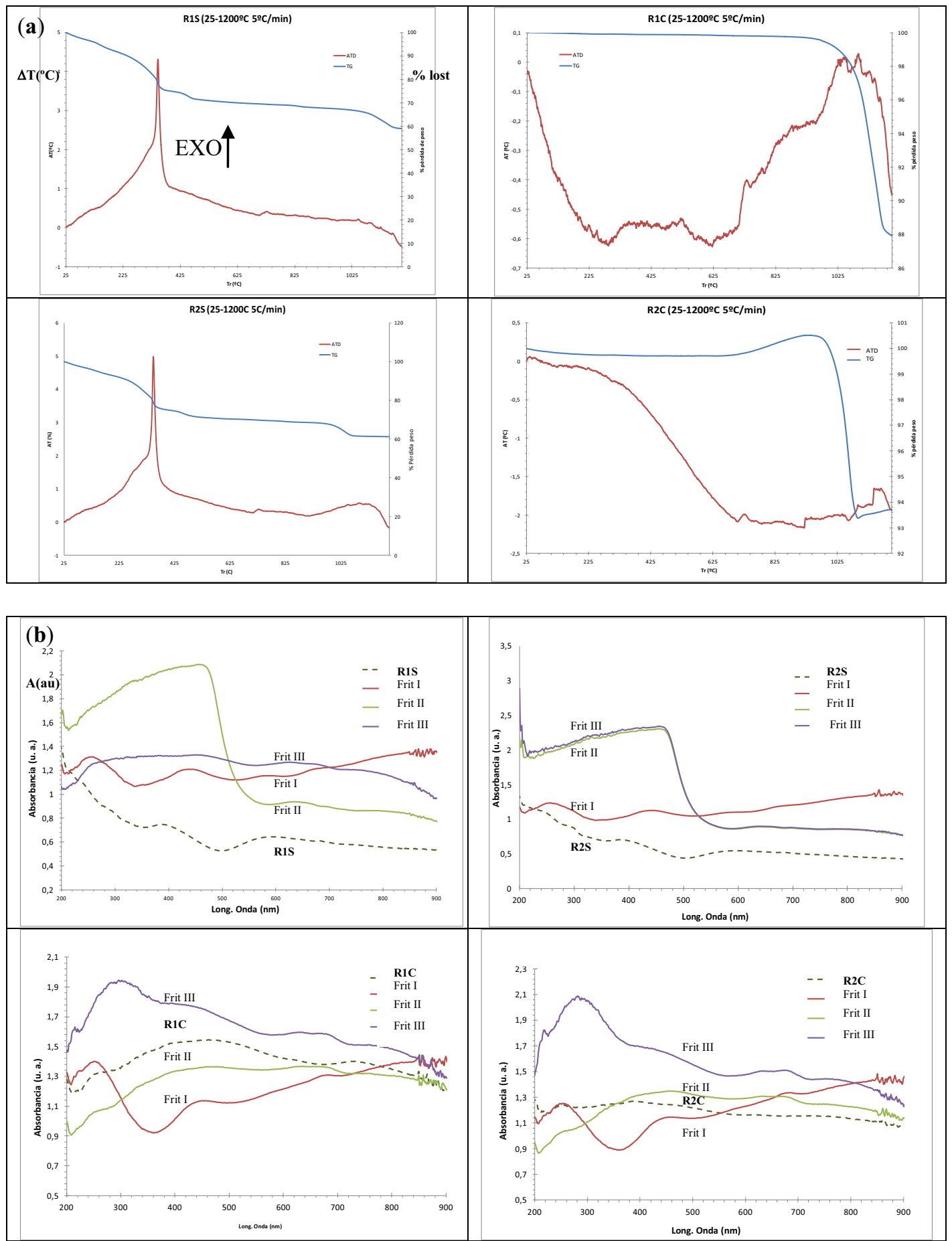
Table 1. SEM micrographs and oxide composition of frits obtained by EDX analysis.

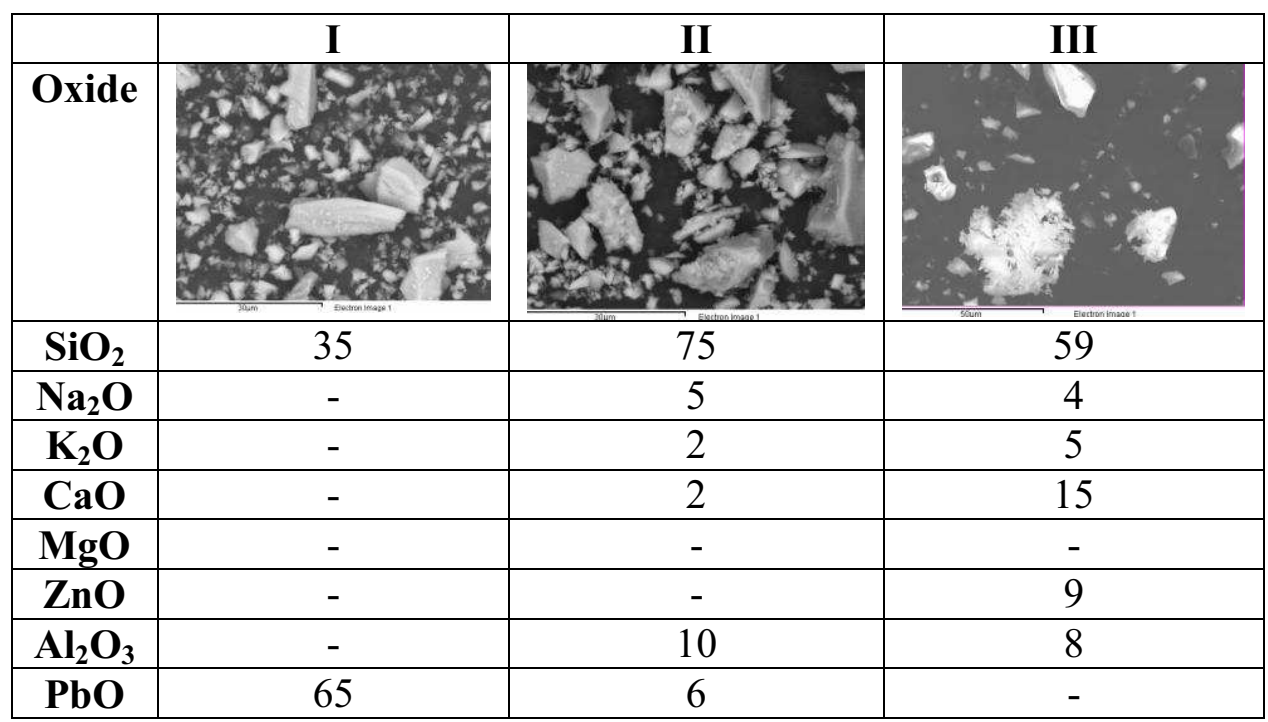


Table 2. SEM micrographs and oxide composition of wastes (dried and fired) obtained by EDX analysis.

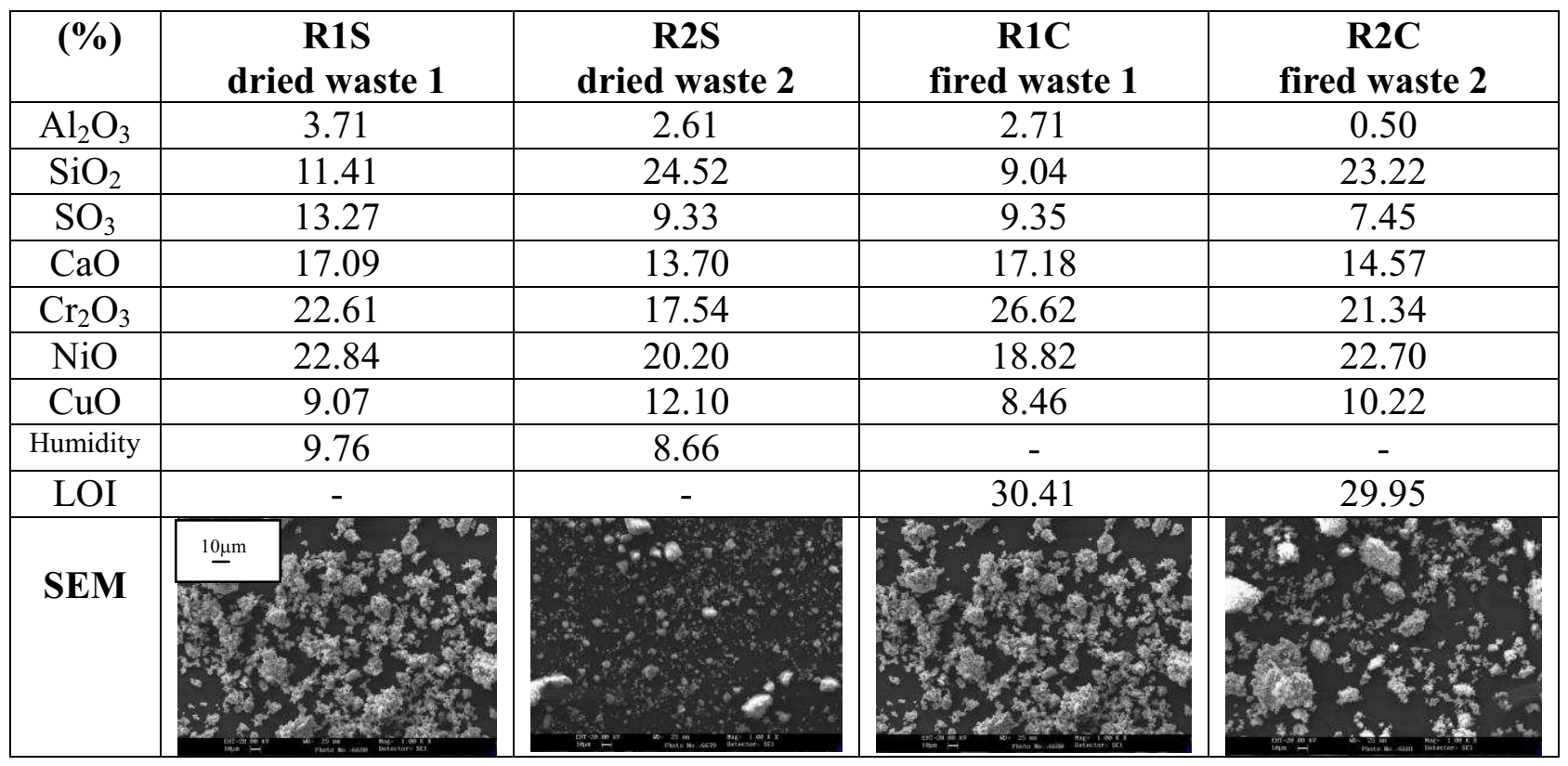

Table 3. $\mathrm{L}^{*} \mathrm{a} * \mathrm{~b}^{*}$ parameters of powders and $5 \mathrm{wt} \%$ glazed samples.

\begin{tabular}{|c|c|c|c|c|c|}
\hline & $\begin{array}{c}\text { R1S } \\
\text { dried waste 1 }\end{array}$ & $\begin{array}{c}\text { R2S } \\
\text { dried waste 2 }\end{array}$ & $\begin{array}{c}\text { R1C } \\
\text { fired waste 1 }\end{array}$ & $\begin{array}{c}\text { R2C } \\
\text { fired waste 2 }\end{array}$ & $\begin{array}{c}\text { STANDARD } \\
\text { Fe-Cr-Mn } \\
\text { spinel. }\end{array}$ \\
\hline powder & $57.4 /-7.2 / 1.6$ & $62.9 /-8.4 / 4.2$ & $21.5 / 2.4 / 3.3$ & $30.7 / 0.6 / 3.5$ & $39.7 /-0.3 / 0.2$ \\
\hline Frit I & $35.8 / 4.3 / 45.8$ & $38.1 / 3.6 / 53.5$ & $25.1 /-0.3 / 0.4$ & $26.7 /-0.2 / 2.1$ & - \\
\hline Frit II & $32.2 /-2.5 / 3.4$ & $34.7 /-3.6 / 1.9$ & $31.4 /-3.3 /-2.7$ & $30.9 /-2.9 /-3.3$ & - \\
\hline Frit III & $28.0 /-0.5 / 3.4$ & $38.1 / 3.6 / 3.5$ & $17.6 /-0.1 / 5.5$ & $20.7 /-0.9 / 6.3$ & $27.7 / 0.1 / 0.8$ \\
\hline
\end{tabular}

